\title{
The impact of democracy and media freedom on under-5 mortality, 1961-2011
}

\author{
Simon Wigley*, Arzu Akkoyunlu-Wigley \\ a Department of Philosophy, Bilkent University, 06800, Bilkent, Ankara, Turkey \\ b Department of Economics, Hacettepe University, 06800, Beytepe, Ankara, Turkey
}

\section{A R T I C L E I N F O}

\section{Article history:}

Received 16 March 2017

Received in revised form

3 August 2017

Accepted 21 August 2017

Available online 24 August 2017

\section{Keywords:}

Democracy

Media freedom

Under-5 mortality

Panel data analysis

Country fixed effects

\begin{abstract}
A B S T R A C T
Do democracies produce better health outcomes for children than autocracies? We argue that (1) democratic governments have an incentive to reduce child mortality among low-income families and (2) that media freedom enhances their ability to deliver mortality-reducing resources to the poorest. A panel of 167 countries for the years $1961-2011$ is used to test those two theoretical claims. We find that level of democracy is negatively associated with under- 5 mortality, and that that negative association is greater in the presence of media freedom. These results are robust to the inclusion of country and year fixed effects, time-varying control variables, and the multiple imputation of missing values.
\end{abstract}

() 2017 Elsevier Ltd. All rights reserved.

\section{Introduction}

Child mortality primarily occurs among the poorest members of society in developed countries and especially developing countries (de Looper and Lafortune, 2009; Yazbeck, 2009). Moreover, it is often due to illnesses that are easy to prevent or treat (via, for example, vaccination, peri- and neonatal care, access to clean water, antibiotics, oral rehydration solutions, etc.). Infectious diseases accounted for $51.8 \%$ of global deaths in children younger than five years in 2013. The largest share of those deaths were due to pneumonia (14.9\%), diarrhea (9.2\%) and malaria (7.2\%) (Liu et al., 2015). Effective interventions exist for all three diseases (Jones et al., 2003). In addition, approximately $45 \%$ of all child deaths were linked to undernutrition in 2011 (Black et al., 2013). This suggests that child mortality rates among the poor could be responsive to public policy-making.

A key determinant of public policy is regime type. Democratic leaders must win the support of a larger share of the population than their autocratic counterparts in order to stay in power. Thus, they have an incentive to provide welfare-promoting resources to a larger proportion of the population. In support of that theoretical

\footnotetext{
* Corresponding author.

E-mail addresses: wigley@bilkent.edu.tr (S. Wigley), arzus@hacettepe.edu.tr (A. Akkoyunlu-Wigley).
}

claim there are a growing number of cross-national studies that find that that democracies produce healthier, more educated and better nourished populations than autocracies (see, for example, Besley and Kudamatsu, 2006; Blaydes and Kayser, 2011; Brown, 1999; Gerring et al., 2012; Mackenbach et al., 2013; Patterson and Veenstra, 2016; Wigley and Akkoyunlu, 2011). It is not immediately obvious, however, that democracies are better at promoting the well-being of the poorest members of society. It remains possible that democratic governments will not target welfare transfers and public goods to low-income citizens because their votes are not required in order to secure a winning majority. Thus, democratic leaders may be no better at reducing child mortality among the poor than autocratic leaders (Ross, 2006).

In response to that challenge we argue, in what follows, that democratic leaders have a greater incentive to reduce child mortality, even in those cases when they do not require the electoral support of low-income voters (section 2.1). This is because of the economic benefits - economies of scale, positive externalities and enhanced productivity - associated with improved child health. In addition, we argue that democracies are better equipped to reduce child mortality because the greater protection they afford to free speech, and especially media freedom, enhances government responsiveness (section 2.2).

In order to test those two theoretical claims we employ a panel of 167 countries (all countries with populations greater than 
250,000) for the years 1961-2011 (sections 3-5). We include country fixed effects in order to control for those unchanging factors, such as climate and colonial history, which might be simultaneously determining regime type and child health. We also employ a measure of democracy that takes into account the two central ingredients of democratic rule, political competition and political participation. Previous studies on the link between democracy and well-being outcomes, have tended to focus on the extent to which there are regular and genuinely competitive elections. As a consequence, they have not taken into account the degree to which citizens actually participate in those elections, or even whether there is universal suffrage. Our measure of democracy, therefore, provides a more complete picture of each country's democratic status.

\section{Theoretical framework}

In this section we develop our two theoretical claims. Namely, that democratic leaders have a greater incentive and capability to reduce child mortality than autocratic leaders. Subsequent sections present empirical evidence in support of those two claims.

\subsection{Democracy and public goods}

The survival of political leaders typically depends on their ability to deliver benefits to their support base. This may take the form of benefits targeted to specific individuals or groups, such as direct payments or government contracts. Alternatively, this may take the form of public goods such as infrastructure, health care and education. Autocratic leaders will typically prefer to provide targeted private goods in order to win the support of their narrow support base. That is because it is less costly to enrich the few than to use public goods in order to benefit everyone. However, as the required number of backers expands it becomes increasingly more costeffective for political leaders to maintain support by producing public goods. Thus, as suffrage is extended private goods represent an increasingly smaller proportion of the benefits doled out by the government. In other words, a transition from autocratic to democratic rule generates a trend away from targeted private benefits and towards public goods (Besley and Kudamatsu, 2006; Bueno de Mesquita et al., 2005; McGuire, 2013).

Fig. 1 provides some evidence in support of that claim based on the 39 states that underwent an unambiguous transition from autocratic rule to democratic rule between 1960 and 2000. We use the binary democracy variable constructed by Cheibub and colleagues (2010) to identify those countries that have transitioned to democratic rule. The bars represent the average emphasis on public goods for each of the 39 states, for each of the 10 years before and after transition. Our measure of the extent to which governments prioritize public goods over targeted goods is taken from the Varieties of Democracy Project (Coppedge et al., 2016) and is based on the responses of multiple country experts. That project uses cross-rater disagreement to estimate, and thereby correct for, measurement error. As we can see there was a noticeable increase in the extent to which those governments prioritized public goods over targeted goods immediately after the transition year. In addition, there is a clear increase in public goods emphasis in the years leading up to the unambiguous transition. This is consistent with a move towards public goods as the regime in each of those countries began to take on more democratic characteristics.

The question is whether the increase in the production of public goods that follows from a democratic transition will also benefit the poor. The kind of publicly provided resources that would be of most value to the worst-off (e.g. access to health practitioners, pharmaceuticals and teachers) may be targeted towards some voters and not others. Thus, it remains possible that low-income voters will be denied sufficient access to social services because they are not required in order to win the election (Ross, 2006). Thus, it is not immediately obvious that the greater emphasis that democracies place on public goods will entail that they are more pro-poor than autocracies. By extension, democratic leaders may lack an electoral incentive to improve child health among the poorest members of society.

We contend that democratic governments have reason to reduce child mortality irrespective of whether they require the support of the poorest citizens. Public goods such as health care and education generate economies of scale, produce positive externalities and enhance worker productivity. Those three factors mean that middle and upper-income voters have a vested interest in extending access to low-income voters. Firstly, the public provisioning of health and educational resources with high fixed costs, such as hospital and school buildings, means that access can be extended to additional citizens at low marginal cost. Secondly, middle and upper-income voters may receive spillover benefits from improvements in the health and education of the poorest. For example, health interventions such as vaccinations will help to prevent the spread of contagious diseases. Equally, providing health care and schooling to the low-income group may help to reduce the possibility of social unrest. Thirdly, and more importantly, middle and upper-income voters may benefit from the effect of human capital formation on economic growth (Lindert, 2004; North et al., 2009, pp. 142-143, 266). Health care provisioning increases the stock of human capital because healthier workers are more productive, disease-free children tend to learn more and the incentive to privately invest in education increases as survival rates improve (Baird et al., 2016; Bleakley, 2007; Soares, 2005).

In a similar vein Lizzeri and Persico (2004) argue that the industrial elite in nineteenth century Britain supported spending on preventative health measures and public education so as to minimize their exposure to disease and to create a more educated labor force. They go on to argue that it was in the self-interest of the majority of the elite to extend the franchise during the 1800's because it increased the likelihood of policy-making orientated towards those kinds of public goods, rather than targeted spending.

Autocratic leaders may also wish to take advantage of the economic benefits associated with health and education. A regime without access to free resources (i.e. natural resource rents and foreign aid) must rely on economic growth in order to increase the tax revenue to be divided amongst its narrow support base (Besley and Kudamatsu, 2008). At the same time, however, they will be averse to investing in human capital for fear of creating a new economic class that may ultimately threaten their grip on power (Ansell, 2010, pp. 6-7, 9-10; Lindert, 2004, chap. 5). Autocratic leaders without access to non-tax revenues must balance the cost of not enabling economic growth against the risk of empowering the low-income group. We assume, therefore, that they will typically invest less in the health and education of the low-income group than democracies.

The upshot of this is that democratic leaders have a greater incentive to reduce child mortality even if it turns out that they do not require the support of the poorest in order to achieve a winning majority. That is because their ability to obtain sufficient support among non-poor voters may depend on their ability to deliver mortality-averting resources to the poorest. The main implication of this theoretical account is,

Hypothesis 1. An increase in the level of democracy will reduce the level of under-5 mortality.

Fig. 2 presents preliminary evidence in support of this hypothesis by examining the association between democratization and 


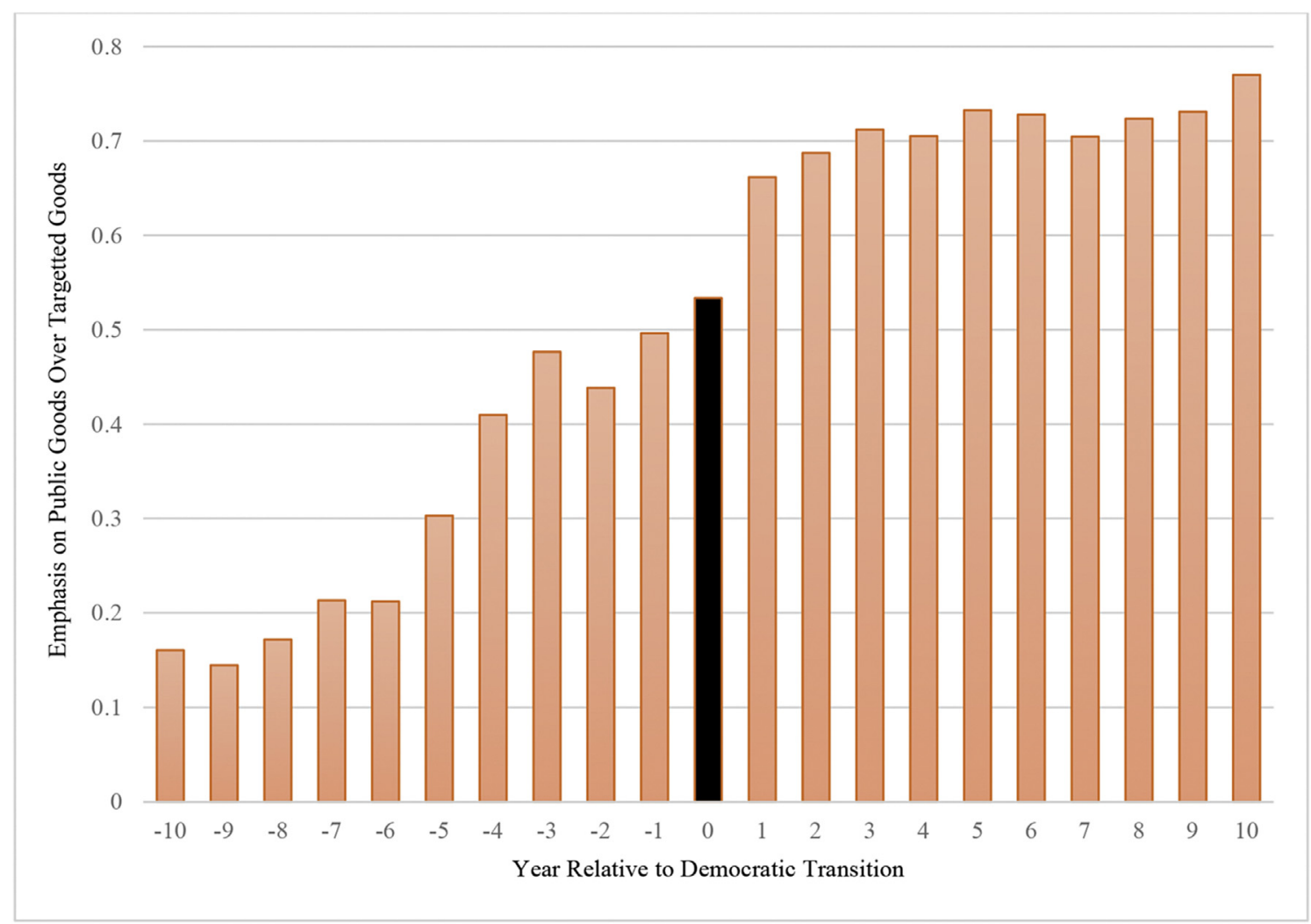

Fig. 1. Public goods emphasis before and after democratic transition for 39 states, $1950-2010$.

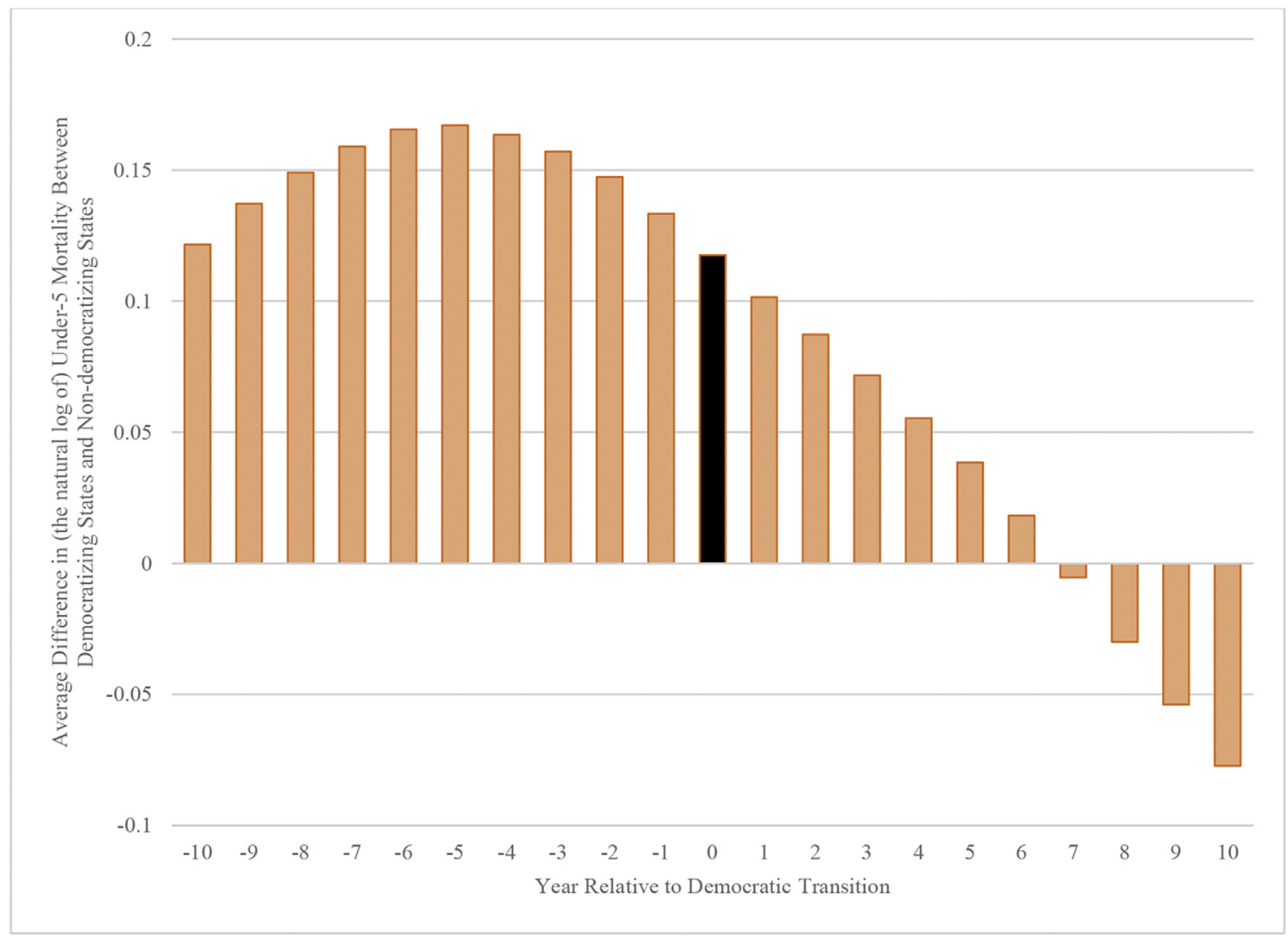

Fig. 2. Relative performance of 11 Sub-Saharan states before and after democratic transition, 1980-2010. 
child mortality in the world's poorest region, Sub-Saharan Africa, between 1980 and 2010. 11 states in that region underwent an unambiguous transition to democracy between 1990 and 2000 (Benin, Cabo Verde, Ghana, Kenya, Madagascar, Malawi, Mali, Nigeria, Sao Tome and Principe, Senegal, and Sierra Leone). We use the same binary variable as before to identify the transition countries. For each of those democratizing countries we subtracted the (natural log of) under-5 mortality from the average (natural log of) under-5 mortality for those countries in the region that remained autocratic throughout the period. Each bar represents the average difference for each year relative to the transition. This enables us to compare the performance of the democratizing countries and nondemocratizing countries in the region for the 10 years before and after the democratic transition.

As we can see the democratizing states were outperformed by the non-democratizing states (i.e. they had a higher under-5 mortality rate on average) until seven years after the transition. However, there is a clear improvement in relative performance during the years immediately before the transition and thereafter. This is consistent with our theoretical claim that democratization increases the incentive for governments to reduce child mortality. Significantly the graph also suggest that the pro-health effects of democratization can emerge over a relatively short period of time (See also, Kudamatsu, 2012). However, this result is at best suggestive. The observed trend may be explained by a confounding factor, such as economic growth, which is determining both the level of democracy and under-5 mortality. We take steps to overcome this and related issues in the panel data analysis that follows.

Two existing studies have shown a robust negative association between the accumulated stock of democracy and infant mortality (Gerring et al., 2012; McGuire, 2013). However, it has proven more difficult to identify a negative association between the level of democracy at each point in time and infant or under-5 mortality. In other words, it has proven difficult to establish that democratic reforms have a positive impact on child health before those reforms have become institutionalized. Some earlier studies did find such a relationship (Franco, 2004; Lake and Baum, 2001; Przeworski, 2000; Zweifel and Navia, 2000). However, those studies are affected either by selection bias because they excluded a number of well-performing autocracies, or by omitted variable bias because they did not control for country fixed effects (Ross, 2006). Moreover, at least four studies have found no clear relationship between the contemporaneous level of democracy and infant or under-5 mortality (Houweling et al., 2005; Ross, 2006; Shandra et al., 2004; Truex, 2015). One of the primary aims of this study, therefore, is to show that a robust negative association between the flow of democracy and under-5 mortality pertains, provided the index of democracy is constructed in a way that takes adequate account of the two key ingredients of democratic rule (i.e. contestation and participation).

\subsection{Media freedom and child mortality}

As a number of scholars have noted the key to improving child health lies with the targeting of public resources, rather than simply the magnitude of those resources (Filmer and Pritchett, 1999; Gauri and Khaleghian, 2002; McGuire, 2006). We have already argued that democratic governments have reason to target the low-income group even if they do not require their electoral support. However, we contend that targeting does not completely explain the comparative advantage of democratic governments over their autocratic counterparts. Improving child health crucially depends on how effectively the poor are targeted. Whether public resources are effectively targeted towards the poor depends, in turn, on the quality of the information available to the government and its citizens. Democracies are able to supply higher quality information than autocracies because they typically afford greater protection to freedom of expression, most notably media freedom.

Media freedom helps to ensure that the right kind of resources actually reach those that need them the most. That is because communication openness helps to overcome two potential sources of imperfect information. One concerns the information available to the government, while the other concerns the information available to citizens. In the first case the government will be better informed about the need for intervention (e.g. disease outbreak) as well as the success of its mortality-reducing policies (e.g. whether government policy is being properly implemented by government officials). In this regard media freedom enhances the ability of the government to select and implement pro-health policies. In the second case, citizens will be better informed about the actions of the government, such that it will be more difficult to hide policy failure. The presence of an independent and uncensored media means that voters are better placed to assess the government's attempts to improve child health. The crucial role of media openness in enabling human development is noted by Amartya Sen (2009, pp. 335-337, 1999, pp. 180-181) (See also, Besley et al., 2002).

Autocratic leaders are typically averse to allowing open communication for fear that it will enable opposition movements to coordinate and overthrow the government (Lohmann, 1994). Restrictions on the flow of information enhances the ability of the regime to prevent collective action, but it also diminishes its ability to ascertain whether its policies are having the desired effect - in the absence of reliable feedback the government cannot be sure that it has selected the right policies or that low-level bureaucrats are properly implementing the government's policies. In short, citizens will be less informed, but so will the government. This shortcoming of autocratic rule was explicitly acknowledged by Chairman Mao after the devastating famine which killed millions in China between 1958 and 1961, as well as by Mikhail Gorbachev after he became the leader of the Soviet Union in the mid-1980s (Egorov et al., 2009, p. 645; Sen, 2009, p. 345). The upshot of this is that, even if autocratic leaders do aim to improve child health, they will be less able to achieve that goal than their democratic counterparts.

Thus, the greater media freedom that typically accompanies the process of democratization helps to ensure that public resources are more effectively targeted towards the low-income group. This implies the following hypothesis,

Hypothesis 2. An increase in the level of media freedom will amplify the reductive effect of the level of democracy on under-5 mortality.

Four existing studies find that media exposure and ownership can influence the willingness and ability of governments to provide welfare-promoting resources. Stromberg (2004), for example, finds that those who have access to a new mass media medium are favored by government policy-making. Besley and Burgess (2002) present evidence that government spending is more responsive to droughts and floods in Indian states with a higher newspaper circulation. Reinikka and Svensson (2005) find that the illicit capture of grants intended for primary schools in Uganda declined markedly after the government made data on the inflow of funds to school and district administrators available to newspapers and radio broadcasters. Finally, Djankov and colleagues (2003) find that less public ownership of the media is associated with better public policy outcomes. In this study we aim to complement those findings by examining whether the presence of independent and uncensored media enhances the ability of democratic governments to reduce child mortality. 


\section{Model, variables and data}

In order to assess the two hypothesis noted above we employ a panel of 167 countries for each year from 1961 to 2011, to analyze the relationship between democracy and under-5 mortality. In order to assess whether level of democracy (as measured by competitive participation) influences the level of under-5 mortality (Hypothesis 1) we employ an additive model of the following form. the polity2 index compiled by the Polity IV project (Marshall and Jaggers, 2016). The polity2 index is based on the extent to which political participation is competitive, the openness and competitiveness of executive recruitment, and the extent to which the chief executive is subject to institutional constraints. Those three components are converted into a 21-point scale for each year, with the most autocratic countries receiving a score of -10 (e.g. North Korea) and the most democratic countries receiving a score

$\ln (\text { Under5 mortality })_{i t+1}=\beta_{0}+\beta_{1}$ Competitive Participation $_{i t}+\beta_{2} \ln (X)_{i t}+u_{i t+1}$

In order to assess whether media freedom conditions the impact of democracy on under-5 mortality (Hypothesis 2 ) we employ a multiplicative model of the following form. of +10 (e.g. Japan). The polity 2 index is a frequently used measure of democracy in the literature and it is probably less susceptible to measurement error than its main rivals (Coppedge

$$
\begin{aligned}
\ln (\text { Under5 mortality })_{i t+1}= & \beta_{0}+\beta_{1} \text { Competitive Participation }_{i t}+\beta_{2} \text { Media Freedom }_{i t}+\beta_{3} \text { Competitive Participation }_{i t} \\
& \times \text { Media Freedom }_{i t}+\beta_{4} \ln (X)_{i t}+u_{i t+1}
\end{aligned}
$$

The additive model captures the average or unconditional effect of competitive participation on under-5 mortality, whereas the multiplicative model captures the conditional effect of competitive participation on under-5 mortality (i.e. the effect of competitive participation in the presence or absence of media freedom).

For both models $i$ is the country, $t$ is the year and $X$ is the set of control variables. In order to take into account the possibility of unmeasured country-specific factors, such as inveterately weak state capacity, culture or climatic conditions, we include country fixed effects. In effect this means we are examining whether changes in the level of democracy (and media freedom) in a single country affect the level of under-5 mortality in that country. In addition, we include year dummies so as to take into account global health trends. Finally, we use the one year lead of the dependent variable to reduce endogeneity.

\subsection{Dependent variable}

Our measure of deprivation is the probability, per 1000 live births, that a newborn baby will die before reaching the age of five (under-5 mortality). Our data source for under-5 mortality is UN Inter-Agency Group for Child Mortality Estimation (Hill et al., 2012; UN IGME, 2016). We use under-5 mortality rather than infant mortality because it is less likely to be affected by undercounting (Anthopolos and Becker, 2010). We assume that it becomes increasingly difficult to achieve a marginal decrease in under-5 mortality as its level is lowered. Moreover, the distribution of that variable is right-skewed. Thus, in the empirical analysis that follows we (following convention) take the natural log transformation of the dependent variable.

\subsection{Independent variables}

The competitive participation variable is based on the two defining characteristics of regime type, the competitiveness of the political process and the extent of participation in the political process (Dahl, 1971). For the first component we rely on et al., 2011; Munck and Verkuilen, 2002).

For all its merits the polity 2 index does have one major shortcoming. Namely, it does not take into account the proportion of the population that is permitted to participate in the selection of public officials (Munck and Verkuilen, 2002, p. 110). Thus, for example, the polity2 index does not take into account the absence of universal suffrage in South Africa before 1994 and at the federal level in Switzerland before 1971. With that shortcoming in mind we use electoral participation to estimate the proportion of citizens that are permitted to participate in the political process. Our measure of electoral participation is the proportion of the total population voting in elections and is taken from Vanhanen (2014). The obvious drawback of using electoral participation is that it includes voter turnout in uncompetitive elections (e.g. elections in one-party states).

In order to overcome the shortcomings of both these measures of democracy, we weight the extent of electoral participation by the degree of competitiveness in the selection of public officials. More precisely, we multiply electoral participation by the polity 2 score divided by the maximum polity 2 score of 21 . The resulting regime variable entails that electoral participation retains its full value in those countries that are fully democratic, whereas it is weighted downwards in those countries where there is insufficient competition in the recruitment of political leaders. This way of combining competition and participation ensures that each is treated as necessary and complementary ingredients of democratic rule (Munck, 2009, pp. 48-49, 59). (In the online appendix we test whether our results are robust to alternative ways of constructing this variable).

For media freedom we use the dichotomous indicator of media freedom that has been constructed by Whitten-Woodring and Van Belle (2014). According to that index, the media environment is classified as free if criticism of government or government officials can and does occur and unfree if it is not possible to safely criticize the government or government officials.

Finally, the fixed effects specification that we use helps to mitigate any omitted variable bias. Nevertheless, it is necessary to 
control for those time-varying factors that might be simultaneously determining the extent of democracy or media freedom as well as the level of under-5 mortality. For that reason we include the natural log of GDP per capita (real gross domestic product per capita in constant 2005 dollars; Heston et al., 2012), urbanization (share of population living in urban areas; World Bank, 2016), trade openness (total trade as a proportion of gross domestic product; Heston et al., 2012), and oil and gas rents (per capita income from oil and gas production, in 2000 constant dollars; Ross and Mahdavi, 2015) in order to control for wealth, economic development, exposure to international competition, and access to non-tax revenue (Wigley, 2017).

\subsection{Data set}

After constructing the data set we found that observations were missing for a small proportion of country-years. Deleting those cases with missing values may deprive the model of relevant information. In addition, it may bias the results if there is a systematic difference between the observed and unobserved data (Ross, 2006). Thus, rather than applying the method of listwise deletion, we use the Amelia multiple imputation algorithm to estimate the missing values (Honaker et al., 2013). Using the multiple imputation process meant we were able to generate a balanced panel composed of the 167 countries that had populations greater than 250,000 during the period 1961 to 2011. This includes those countries that became independent during those years. In order to ensure the robustness of our findings we also run the two models using the original, non-imputed, data set (see section 5 below). Detailed variable descriptions and descriptive statistics, as well as a complete explanation of the multiple imputation process, can be found in the online appendix. The online appendix also outlines the adjustments that were made to the Polity IV variables for those states that became independent from a contiguous empire, or that emerged as a result of unification or division.

\section{Results}

The results of our analysis are presented in Table 1 . The first three columns present the results of the additive model and the next two columns present the results of the multiplicative model. The remaining columns provide robustness checks for our baseline results.

\subsection{Additive model}

Does level of democracy play a role in determining the level of under-5 mortality? (Hypothesis 1) As we can see from column 1 our measures of participation (electoral participation) and political competition (polity2) are statistically significant and carry the expected sign. Unsurprisingly, therefore, our composite measure of democracy, where electoral participation is weighted by the degree of political competition (competitive participation), is also significant and carries the expected sign (column 2). We also examined the average effect of media freedom on under-5 mortality (column
3). As we can see media freedom is negatively associated with under-5 mortality, but it does not achieve statistical significance. This is consistent with our claim that media freedom does not affect child health independently of democracy, but rather modifies the impact of democracy. With that in mind we now turn to consider whether media freedom conditions the reductive effect of competitive participation on under-5 mortality.

\subsection{Multiplicative model}

Is the salutary impact of democracy on child health dependent on whether there are independent and uncensored media? (Hypothesis 2) As we can see from column 4 all the variables of interest are statistically significant. Unlike the additive model, the coefficients for the constitutive terms do not represent the average effect (i.e. unconditional effect) of competitive participation or media freedom on under-5 mortality (Brambor et al., 2006, pp. 71-73). The coefficient for the constitutive term for media freedom represents the marginal effect of that variable when the regime is fully autocratic (e.g. North Korea). Note, however, it would be highly unusual for a fully autocratic country to permit media freedom. Nevertheless, the coefficient suggests that the salutary effect of media freedom on under-5 mortality is dependent upon the presence of a sufficient level of competitive participation. The coefficient for the constitutive term for competitive participation represents the marginal effect of that variable on under- 5 mortality when there is no media freedom. As we can see the salutary effect of competitive participation is not dependent upon the presence of media freedom. From the coefficient of the interaction term we can see that the marginal salutary effect of competitive participation on under-5 mortality increases when media are free.

Taken together these results indicate that there is negative association between competitive participation and under- 5 mortality when there is no media freedom, and that that negative association is even greater when there is media freedom. That finding, combined with the observation that democracies typically afford greater protection to media freedom, suggests that they have a comparative advantage with respect to reducing under-5 mortality. In other words, it lends support to the claim that the greater communication openness produced by democratic states enhances the government's ability to improve child health.

Column 5 represents a side test for the claim underlying Hypothesis 2. Namely, the claim that media freedom enhances the government's ability to deliver mortality-reducing resources to the poorest. More precisely, it examines whether the negative association between government provisioning and under-5 mortality is magnified in the presence of media freedom. It is important to note that the question here is not how much the government provides, but rather how well it targets the resources it does provide. As we have already noted mortality-reduction largely depends on the targeting of resources, rather than simply the extent of those resources (see section 2.2). Thus, we take the magnitude of government provisioning as given and investigate whether the impact of those resources on under-5 mortality is conditioned by media freedom. The model takes the following form:

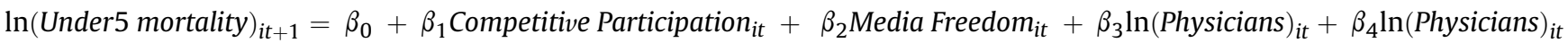

$$
\begin{aligned}
& \times \text { Media Freedom }_{i t}+\beta_{5} \ln (X)_{i t}+u_{i t+1}
\end{aligned}
$$


Table 1

Democracy, media freedom and under-5 mortality.

\begin{tabular}{|c|c|c|c|c|c|c|c|c|c|c|c|c|c|}
\hline & (1) & (2) & (3) & (4) & (5) & (6) & (7) & (8) & (9) & (10) & (11) & (12) & (13) \\
\hline & \multicolumn{3}{|c|}{ Additive model } & \multicolumn{2}{|c|}{ Multiplicative model } & \multicolumn{2}{|c|}{ Without fixed effects } & \multicolumn{2}{|c|}{$\begin{array}{l}\text { Lagged dependent } \\
\text { variable }\end{array}$} & \multicolumn{2}{|c|}{ Driscoll-Kraay SE } & \multicolumn{2}{|l|}{ Non-imputed } \\
\hline $\begin{array}{l}\text { Electoral participation } \\
\text { Polity2 }\end{array}$ & $\begin{array}{l}-0.00217^{* * *} \\
(0.000672) \\
-0.00447^{*} \\
(0.00245)\end{array}$ & & & & & & & & & & & & \\
\hline Competitive participation & & $\begin{array}{l}-0.00359^{* * *} \\
(0.00104)\end{array}$ & & $\begin{array}{l}-0.00291^{* * *} \\
(0.00107)\end{array}$ & $\begin{array}{l}-0.00305^{* * *} \\
(0.000988)\end{array}$ & $\begin{array}{l}-0.00376^{* * *} \\
(0.00103)\end{array}$ & $\begin{array}{l}-0.00307^{* * *} \\
(0.00106)\end{array}$ & $\begin{array}{l}-0.00111^{* * *} \\
(0.000387)\end{array}$ & $\begin{array}{l}-0.00122^{* *} \\
(0.000464)\end{array}$ & $\begin{array}{l}-0.00359 * * * \\
(0.000526)\end{array}$ & $\begin{array}{l}-0.00291^{* * *} \\
(0.000792)\end{array}$ & $\begin{array}{l}-0.00266^{* * *} \\
(0.000999)\end{array}$ & $\begin{array}{l}-0.00189^{* *} \\
(0.000910)\end{array}$ \\
\hline Media freedom & & & $\begin{array}{l}-0.0104 \\
(0.0286)\end{array}$ & $\begin{array}{l}0.0972^{* *} \\
(0.0404)\end{array}$ & $\begin{array}{l}0.0728^{* *} \\
(0.0353)\end{array}$ & & $\begin{array}{l}0.102^{* *} \\
(0.0402)\end{array}$ & & $\begin{array}{l}0.0229 \\
(0.0165)\end{array}$ & & $\begin{array}{l}0.0972^{* * *} \\
(0.0185)\end{array}$ & & $\begin{array}{l}0.0785^{* *} \\
(0.0384)\end{array}$ \\
\hline Competitive participation $\times$ Media freedom & & & & $\begin{array}{l}-0.00275^{* *} \\
(0.00132)\end{array}$ & & & $\begin{array}{l}-0.00286^{* *} \\
(0.00132)\end{array}$ & & $\begin{array}{l}-0.000314 \\
(0.000630)\end{array}$ & & $\begin{array}{l}-0.00275^{* * *} \\
(0.000591)\end{array}$ & & $\begin{array}{l}-0.00232^{*} \\
(0.00124)\end{array}$ \\
\hline Physicians (ln) & & & & & $\begin{array}{l}-0.142^{* * *} \\
(0.0367)\end{array}$ & & & & & & & & \\
\hline Physicians $(\mathrm{ln}) \times$ Media freedom & & & & & $\begin{array}{l}-0.0846^{* *} \\
(0.0423) \\
\end{array}$ & & & & & & & & \\
\hline GDP per capita (ln) & $\begin{array}{l}-0.390^{* * *} \\
(0.0333)\end{array}$ & $\begin{array}{l}-0.386^{* * *} \\
(0.0334)\end{array}$ & $\begin{array}{l}-0.392^{* * *} \\
(0.0337)\end{array}$ & $\begin{array}{l}-0.383^{* * *} \\
(0.0338)\end{array}$ & $\begin{array}{l}-0.362^{* * *} \\
(0.0333)\end{array}$ & $\begin{array}{l}-0.394^{* * *} \\
(0.0325)\end{array}$ & $\begin{array}{l}-0.390^{* * *} \\
(0.0329)\end{array}$ & $\begin{array}{l}-0.166^{* * *} \\
(0.0259)\end{array}$ & $\begin{array}{l}-0.166^{* * *} \\
(0.0260)\end{array}$ & $\begin{array}{l}-0.386^{* * *} \\
(0.0302)\end{array}$ & $\begin{array}{l}-0.383^{* * *} \\
(0.0305)\end{array}$ & $\begin{array}{l}-0.347^{* * *} \\
(0.0519)\end{array}$ & $\begin{array}{l}-0.343^{* * *} \\
(0.0522)\end{array}$ \\
\hline Urbanization (ln) & $\begin{array}{l}0.283^{* * *} \\
(0.0668)\end{array}$ & $\begin{array}{l}0.263^{* * * *} \\
(0.0677)\end{array}$ & $\begin{array}{l}0.279^{* * *} \\
(0.0687)\end{array}$ & $\begin{array}{l}0.244^{* * *} \\
(0.0690)\end{array}$ & $\begin{array}{l}0.227^{* * *} \\
(0.0702)\end{array}$ & $\begin{array}{l}0.234^{* * *} \\
(0.0642)\end{array}$ & $\begin{array}{l}0.216^{* * *} \\
(0.0652)\end{array}$ & $\begin{array}{l}0.0750^{* *} \\
(0.0290)\end{array}$ & $\begin{array}{l}0.0717^{* *} \\
(0.0295)\end{array}$ & $\begin{array}{l}0.263^{* * *} \\
(0.0288)\end{array}$ & $\begin{array}{l}0.244^{* * *} \\
(0.0295)\end{array}$ & $\begin{array}{l}0.331^{* * *} \\
(0.0731)\end{array}$ & $\begin{array}{l}0.311^{* * *} \\
(0.0743)\end{array}$ \\
\hline Trade openness (ln) & $\begin{array}{l}-0.0641^{* * *} \\
(0.0216)\end{array}$ & $\begin{array}{l}-0.0613^{* * *} \\
(0.0221)\end{array}$ & $\begin{array}{l}-0.0667^{* * *} \\
(0.0219)\end{array}$ & $\begin{array}{l}-0.0618^{* * *} \\
(0.0221)\end{array}$ & $\begin{array}{l}-0.0682^{* * *} \\
(0.0213)\end{array}$ & $\begin{array}{l}-0.0616^{* * *} \\
(0.0218)\end{array}$ & $\begin{array}{l}-0.0621^{* * *} \\
(0.0217)\end{array}$ & $\begin{array}{l}-0.0302^{* * *} \\
(0.0102)\end{array}$ & $\begin{array}{l}-0.0308^{* * *} \\
(0.0103)\end{array}$ & $\begin{array}{l}-0.0613^{* * *} \\
(0.0127)\end{array}$ & $\begin{array}{l}-0.0618^{* * *} \\
(0.0129)\end{array}$ & $\begin{array}{l}-0.0694^{*} \\
(0.0382)\end{array}$ & $\begin{array}{l}-0.0695^{*} \\
(0.0380)\end{array}$ \\
\hline Oil \& gas rents (ln) & $\begin{array}{l}0.0323^{* * *} \\
(0.00813)\end{array}$ & $\begin{array}{l}0.0299^{* * * *} \\
(0.00810)\end{array}$ & $\begin{array}{l}0.0323^{* * *} \\
(0.00816)\end{array}$ & $\begin{array}{l}0.0302^{* * *} \\
(0.00798)\end{array}$ & $\begin{array}{l}0.0287^{* * *} \\
(0.00773)\end{array}$ & $\begin{array}{l}0.0300^{* * *} \\
(0.00791)\end{array}$ & $\begin{array}{l}0.0303^{* * *} \\
(0.00780)\end{array}$ & $\begin{array}{l}0.0121^{* * * *} \\
(0.00389)\end{array}$ & $\begin{array}{l}0.0123^{* * *} \\
(0.00391)\end{array}$ & $\begin{array}{l}0.0299 * * * \\
(0.00631)\end{array}$ & $\begin{array}{l}0.0302^{* * *} \\
(0.00613)\end{array}$ & $\begin{array}{l}0.0361^{* * * *} \\
(0.0107)\end{array}$ & $\begin{array}{l}0.0338^{* * *} \\
(0.0105)\end{array}$ \\
\hline Lag dependent variable & & & & & & & & $\begin{array}{l}0.684^{* * * *} \\
(0.0386) \\
\end{array}$ & $\begin{array}{l}0.683^{* * * *} \\
(0.0385) \\
\end{array}$ & & & & \\
\hline Ethnic fractionalization & & & & & & $\begin{array}{l}-0.0458 \\
(0.127)\end{array}$ & $\begin{array}{l}-0.0445 \\
(0.126)\end{array}$ & & & & & & \\
\hline Landlocked & & & & & & $\begin{array}{l}0.214^{* * *} \\
(0.0710)\end{array}$ & $\begin{array}{l}0.211^{* * *} \\
(0.0700)\end{array}$ & & & & & & \\
\hline Temperate & & & & & & $\begin{array}{l}-0.643^{* * *} \\
(0.0901)\end{array}$ & $\begin{array}{l}-0.629^{* * *} \\
(0.0881)\end{array}$ & & & & & & \\
\hline Year fix & $\checkmark$ & $\checkmark$ & $\checkmark$ & $\checkmark$ & $\checkmark$ & $\checkmark$ & $\checkmark$ & $\checkmark$ & $\checkmark$ & $\checkmark$ & $\checkmark$ & $\checkmark$ & $\checkmark$ \\
\hline Country fixed effects & $\checkmark$ & $\checkmark$ & $\checkmark$ & $s$ & $\checkmark$ & & & $s$ & $\checkmark$ & $\checkmark$ & $s$ & $\checkmark$ & $\checkmark$ \\
\hline World region dummies & & & & & & $\checkmark$ & $\checkmark$ & & & & & & \\
\hline Legal origin dummies & & & & & & $\checkmark$ & $\checkmark$ & & & & & & \\
\hline Countries & 167 & 167 & 167 & 167 & 167 & 167 & 167 & 167 & 167 & 167 & 167 & 165 & 165 \\
\hline Years & $1961-2011$ & $1961-2011$ & $1961-2011$ & $1961-2011$ & $1961-2011$ & $1961-2011$ & $1961-2011$ & $1961-2011$ & $1961-2011$ & 1961-2011 & $1961-2011$ & $1961-2011$ & $1961-2011$ \\
\hline Observations & 8517 & 8517 & 8517 & 8517 & 8517 & 8517 & 8517 & 8350 & 8350 & 8517 & 8517 & 6777 & 6767 \\
\hline
\end{tabular}

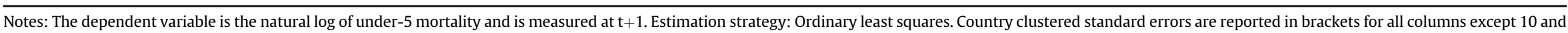
11. Driscoll-Kraay standard errors reported in brackets for columns 10 and 11 . Each country-year represents a single observation. ${ }^{* * *}$ significant at $1 \% ;{ }^{* *} 5 \% ;{ }^{*} 1 \%$. 
We take the natural log of the number of physicians per 1000 inhabitants (physicians) as our indicator of government health provisioning because data for that variable is available for each country and for the entire period under study (World Bank, 2016). Competitive participation is included so as to control for the possibility that the media freedom variable is merely capturing the degree of participation and contestation. We include the same set of time-varying control variables as before. As we can see from column 5 , media freedom magnifies the negative association between the number of physicians and under-5 mortality. This is consistent with the claim that countries with free media are better able to convert health-promoting resources into favorable health outcomes. Nevertheless, this finding should be treated with a degree of caution. Although data coverage for number of physicians is greater than is the case for other provisioning indicators, it remains the case that a high proportion of values are missing for that variable (see online appendix, Table A.3).

\section{Robustness checks}

Fixed effects specifications are crucial as they provide a way to control for unchanging or slow changing factors (physical geography, culture, colonial history, etc.) that may be simultaneously determining the main independent variables of interest and the dependent variable, thereby producing spurious correlations. However, that type of specification has a tendency to underestimate the significance of variables that do not change or are slow changing over time. We therefore ran the additive and multiplicative models without country fixed effects, but with a range of controls for fixed factors. Those time-invariant controls are ethnic fractionalization (Alesina et al., 2003), landlocked, temperate climate (Gallup et al., 2010), world region, and legal origin (La Porta et al., 1999). As we can see from columns 6 and 7, the results are very similar to those obtained for the baseline estimations.

Columns 8 and 9 address the possibility that the right and left hand variables of interest might lead to spurious results if they are both highly trended. In order to control for that possibility we included the lag of the dependent variable on the right-hand side for both model specifications. For this model the political variables are predicting annual changes in the dependent variable, as opposed to the level of the dependent variable. This method for detrending the data produced results that are consistent with our baseline estimations for the additive model (column 8). However, the constitutive term for media freedom and the interaction term lose significance when the lagged dependent variable is added to the multiplicative model (column 9). That may be because the dichotomous media freedom variable does not change quickly enough to create meaningful variance on a year-to-year basis.

We also examined whether our results are affected by the presence of spatial correlation. In this study we have used robust standard errors clustered at the country level to correct for the detected presence of heteroscedasticity and temporal correlation. Pesaran's CD test did not reveal the presence of spatial correlation. Nevertheless, we re-ran the baseline models using Driscoll-Kraay standard errors in order to correct for that possibility. As we can see from columns 10 and 11 this tended to improve the significance levels of each of the coefficients, which in itself suggests the absence of spatial dependence (Hoechle, 2007, pp. 303-304).

Finally, we examined whether our baseline results held when the models were estimated based on the non-imputed data set. Reassuringly, the results are very similar to the baseline estimations suggesting that our findings are not simply an artifact of the imputation model (see columns 12 and 13). However, we prefer to rely on the estimations that are based on the data sets that are produced by multiple imputation because that allows us to include more information and to avoid the possibility of selection bias (e.g. the listwise deletion of undemocratic countries that perform well with respect to mortality-reduction).

In the online appendix (section A.5) we also examine whether our results are sensitive to the way in which the competitive participation variable is constructed. Reassuringly our results hold when that variable is reconstructed based on adult suffrage rather than voter turnout, as well as a more precise measure of political competition. We also find that our baseline results hold when an alternative indicator of media freedom is employed.

\section{Discussion and conclusion}

In this study we have argued that democratic governments have a greater incentive and capability to reduce child mortality among the poor than their autocratic counterparts. In the first place, they have more of an incentive to pursue the economic benefits associated with improved child health. That is, they have reason to improve child health among the poorest even if they do not require their votes in order to secure a winning majority. In the second place, they are better at redirecting health-promoting resources to the poorest because media freedom enhances government responsiveness. In support of those two explanatory claims we have presented robust evidence that (1) there is a negative association between the level of democracy and under-5 mortality, and (2) that that negative association is greater in the presence of media freedom. We have also presented tentative evidence that the negative association between government health provisioning and under-5 mortality is greater in the presence of media freedom. These findings suggest that the extent to which the poorest citizens are able to benefit from public policy is, at least in part, dependent on the presence of democratic institutions and the extent to which the government is vulnerable to criticism from independent and uncensored media.

The results of this study are consistent with Amartya Sen's seminal finding that a famine has a not occurred in an independent country that is characterized by regular and competitive elections, as well as a relatively free press (Sen, 2009, pp. 152-153). Sen's study informs us about the ability of democratic governments to respond to major shocks that threaten the poor, but it does not inform us about the ability of those governments to alleviate the ongoing suffering of the poor (e.g. child mortality, illiteracy, malnutrition etc.) (Drèze and Sen, 1991, pp. 6-7). Thus, our study builds upon and extends Sen's finding by showing that democratic governments typically outperform autocratic governments when it comes to combating endemic deprivation, as measured by under- 5 mortality.

Our study also complements two existing studies that find a robust negative association between democratic experience and infant mortality (Gerring et al., 2012; McGuire, 2013). We find a robust negative association between the level of democracy at each point in time and under- 5 mortality. This suggests that the salutary effect of democratic institutions on child mortality is not wholly dependent on the length of time in which those institutions have been in place. This is significant as it suggests that democratic reforms can have a beneficial effect on child health from the outset (see also Fig. 2).

In addition, our indicator of the level of democracy takes into account the two central elements of democratic rule, contestation and participation. Many of the existing studies on the link between democracy and health rely on indicators of democratic status that do not include electoral turnout, or even suffrage. As a result, they do not take into account the potential importance of participation for public health.

Finally, this study moves beyond the existing literature by 
offering direct evidence that media freedom enhances the ability of democratic governments to reduce child mortality. This, we have argued, is due to the fact that independent and uncensored media improve the quality of the information available to citizens and elected officials.

Taken together these results suggest that democratic reform - in terms of enhanced competition, participation and media freedom can encourage and enable governments to implement policies that improve child survival rates. This is significant given that a high proportion of child deaths around the world can be prevented through the implementation of simple and low-cost interventions.

\section{Acknowledgements}

The authors are grateful for the financial support that they received from the Scientific and Research Council of Turkey (TÜBITAK) (Project number: 114K765). An earlier version of this article was presented to the ECPR workshop 'Was Plato Right: Should Experts Rule?' at the Scuola Normale Superiore, Pisa, 24-25 April, 2016. The authors are grateful to the participants in that workshop for their comments.

\section{Appendix A. Supplementary data}

Supplementary data related to this article can be found at http:// dx.doi.org/10.1016/j.socscimed.2017.08.023.

\section{References}

Alesina, A., Devleeschauwer, A., Easterly, W., Kurlat, S., Wacziarg, R., 2003. Fractionalization. J. Econ. Growth 8, 155-194. http://dx.doi.org/10.1023/A: 1024471506938.

Ansell, B.W., 2010. From the Ballot to the Blackboard: the Redistributive Political Economy of Education. Cambridge University Press, Cambridge.

Anthopolos, R., Becker, C.M., 2010. Global infant mortality: correcting for undercounting. World Dev. 38, 467-481. http://dx.doi.org/10.1016/ j.worlddev.2009.11.013.

Baird, S., Hicks, J.H., Kremer, M., Miguel, E., 2016. Worms at work: long-run impacts of a child health investment. Q. J. Econ. 131, 1637-1680. http://dx.doi.org/ $10.1093 /$ qje/qjw022.

Besley, T., Burgess, R., 2002. The political economy of government responsiveness: theory and evidence from India. Q. J. Econ. 117, 1415-1451. http://dx.doi.org/ $10.1162 / 003355302320935061$.

Besley, T., Kudamatsu, M., 2008. Making autocracy work. In: Helpman, E. (Ed.), Institutions and Economic Performance. Harvard University Press, Cambridge Mass, pp. 452-510.

Besley, T., Kudamatsu, M., 2006. Health and democracy. Am. Econ. Rev. 96, 313-318. http://dx.doi.org/10.1257/000282806777212053.

Besley, T., Robin, B., Prat, A., 2002. Mass media and political accountability. In: Islam, R., Djankov, S., McLeish, C. (Eds.), The Right to Tell: the Role of Mass Media in Economic Development. World Bank, Washington DC., pp. 45-60

Black, R.E., Victora, C.G., Walker, S.P., Bhutta, Z.A., Christian, P., de Onis, M. Ezzati, M., Grantham-McGregor, S., Katz, J., Martorell, R., Uauy, R., 2013. Maternal and child undernutrition and overweight in low-income and middleincome countries. Lancet 382, 427-451. http://dx.doi.org/10.1016/S01406736(13)60937-X.

Blaydes, L., Kayser, M.A., 2011. Counting calories: democracy and distribution in the developing world: counting calories. Int. Stud. Q. 55, 887-908. http:/ dx.doi.org/10.1111/j.1468-2478.2011.00692.x.

Bleakley, H., 2007. Disease and development: evidence from hookworm eradication in the american South. Q. J. Econ. 122, 73-117. http://dx.doi.org/10.1162 qjec.121.1.73.

Brambor, T., Clark, W.R., Golder, M., 2006. Understanding interaction models: improving empirical analyses. Polit. Anal. 14, 63-82. http://dx.doi.org/10.1093/ pan/mpi014.

Brown, D.S., 1999. Reading, writing, and regime type: democracy's impact on primary school enrollment. Polit. Res. Q. 52, 681-707. http://dx.doi.org/10.2307/ 449181.

Bueno de Mesquita, B., Smith, A., Siverson, R.M., Morrow, J.D., 2005. The Logic of Political Survival. MIT Press, Cambridge, Mass.

Cheibub, J.A., Gandhi, J., Vreeland, J.R., 2010. Democracy and dictatorship revisited. Public Choice 143, 67-101. http://dx.doi.org/10.1007/s11127-009-9491-2.

Coppedge, M., Gerring, J., Altman, D., Bernhard, M., Fish, S., Hicken, A., Kroenig, M., Lindberg, S.I., McMann, K., Paxton, P., Semetko, H.A., Skaaning, S.-E., Staton, J., Teorell, J., 2011. Conceptualizing and measuring democracy: a new approach. Perspect. Polit. 9, 247-267. http://dx.doi.org/10.1017/S1537592711000880.
Coppedge, M., Gerring, J., Lindberg, S.I., Skaaning, S.-E., Teorell, J., Altman, D., Bernhard, M., Fish, M.S., Glynn, A., Hicken, A., Knutsen, C.H., Marquardt, K., McMann, K., Miri, F., Paxton, P., Pemstein, D., Staton, J., Tzelgov, E., Wang, Y., Zimmerman, B., 2016. V-dem [Country-Year/Country-Date] dataset v6.2 [WWW document]. Varieties of democracy (V-Dem) project. https://www.v-dem.net. (Accessed 17 February 2017).

Dahl, R.A., 1971. Polyarchy: Participation and Opposition. Yale University Press.

de Looper, M., Lafortune, G., 2009. Measuring Disparities in Health Status and in Access and Use of Health Care in OECD Countries. OECD Health Working Papers. OECD Publishing, Paris.

Djankov, S., McLiesh, C., Nenova, T., Shleifer, A., 2003. Who owns the media? J. Law Econ. 46, 341-382. http://dx.doi.org/10.1086/jle.2003.46.issue-2.

Drèze, J., Sen, A. (Eds.), 1991. The Political Economy of Hunger. Entitlement and Well-being, vol. 1. Oxford University Press. http://dx.doi.org/10.1093/acprof: oso/9780198286356.001.0001.

Egorov, G., Guriev, S., Sonin, K., 2009. Why resource poor dictators allow freer media: theory and evidence from panel data. Am. Polit. Sci. Rev. 103, 645-668.

Filmer, D., Pritchett, L., 1999. The impact of public spending on health: does money matter? Soc. Sci. Med. 49, 1309-1323.

Franco, A., 2004. Effect of democracy on health: ecological study. BMJ 329, 1421-1423. http://dx.doi.org/10.1136/bmj.329.7480.1421.

Gallup, J.L., Mellinger, A.D., Sachs, J.D., 2010. Geography datasets [WWW document]. Center for international development dataverse. http://hdl.handle.net/ 1902.1/14429. (Accessed 24 May 2016).

Gauri, V., Khaleghian, P., 2002. Immunization in developing countries: its political and organizational determinants. World Dev. 30, 2109-2132. http://dx.doi.org/ 10.1016/S0305-750X(02)00151-1.

Gerring, J., Thacker, S.C., Alfaro, R., 2012. Democracy and human development. J. Polit. 74, 1-17. http://dx.doi.org/10.1017/S0022381611001113.

Heston, A., Summers, R., Aten, B., 2012. Penn World Table 7.1, Center for International Comparisons of Production. Income and Prices at the University of Pennsylvania [WWW Document]. http://www.rug.nl/research/ggdc/data/pwt/ pwt-7.1. (Accessed 20 December 2015).

Hill, K., You, D., Inoue, M., Oestergaard, M.Z., 2012. Child mortality estimation: accelerated progress in reducing global child mortality. PLOS Med. 9, 1-11.

Hoechle, D., 2007. Robust standard errors for panel regressions with cross-sectional dependence. Stata J. 7, 281-312.

Honaker, J., King, G., Blackwell, M., 2013. Amelia II: a program for missing data [WWW document]. http://gking.harvard.edu/amelia/.

Houweling, T.A.J., Caspar, A.E.K., Looman, W.N., Mackenbach, J.P., 2005. Determinants of under-5 mortality among the poor and the rich: a cross-national analysis of 43 developing countries. Int. J. Epidemiol. 34, 1257-1265. http:// dx.doi.org/10.1093/ije/dyi190.

Jones, G., Steketee, R.W., Black, R.E., Bhutta, Z.A., Morris, S.S., 2003. How many child deaths can we prevent this year? Lancet 362, 65-71. http://dx.doi.org/10.1016/ S0140-6736(03)13811-1.

Kudamatsu, M., 2012. Has democratization reduced infant mortality in sub-Saharan Africa? Evidence from micro data. J. Eur. Econ. Assoc. 10, 1294-1317.

La Porta, R., Lopez-de-Silanes, F., Shleifer, A., Vishny, R., 1999. The quality of government. JLEO 15, 222-279. http://dx.doi.org/10.1093/jleo/15.1.222.

Lake, D.A., Baum, M.A., 2001. The invisible hand of democracy: political control and the provision of public services. Comp. Polit. Stud. 34, 587-621.

Lindert, P.H., 2004. Growing Public: Volume 1 Social Spending and Economic Growth since the Eighteenth Century. Cambridge University Press, Cambridge.

Liu, L., Oza, S., Hogan, D., Perin, J., Rudan, I., Lawn, J.E., Cousens, S., Mathers, C., Black, R.E., 2015. Global, regional, and national causes of child mortality in 2000-13, with projections to inform Post-2015 priorities: an updated systematic analysis. Lancet 385, 430-440. http://dx.doi.org/10.1016/S01406736(14)61698-6.

Lizzeri, A., Persico, N., 2004. Why did the elites extend the Suffrage? Democracy and the scope of government, with an application to Britain's age of reform. Q. J. Econ. 119, 707-765.

Lohmann, S., 1994. The dynamics of informational cascades: the monday demonstrations in leipzig east Germany 1989-91. World Polit. 47, 42-101.

Mackenbach, J.P., Hu, Y., Looman, C.W.N., 2013. Democratization and life expectancy in europe, 1960-2008. Soc. Sci. Med. 93, 166-175. http://dx.doi.org/10.1016/ j.socscimed.2013.05.010.

Marshall, M.G., Jaggers, K., 2016. Polity IV project: political regime characteristics and transitions, 1800-2015 [WWW document]. http://www.systemicpeace. org/inscrdata.html.

McGuire, J.W., 2013. Political regime and social performance. Contemp. Polit. 19, 55-75. http://dx.doi.org/10.1080/13569775.2013.773203.

McGuire, J.W., 2006. Basic health care provision and Under-5 mortality: a crossnational study of developing countries. World Dev. 34, 405-425.

Munck, G.L., 2009. Measuring Democracy: A Bridge between Scholarship and Politics. Johns Hopkins University Press.

Munck, G.L., Verkuilen, J., 2002. Conceptualizing and measuring democracy: evaluating alternative indices. Comp. Polit. Stud. 35, 5-34.

North, D.C., Wallis, J.J., Weingast, B.R., 2009. Violence and Social Orders: a Conceptual Framework for Interpreting Recorded Human History. Cambridge University Press.

Patterson, A.C., Veenstra, G., 2016. Politics and population health: testing the impact of electoral democracy. Health \& Place 40, 66-75. http://dx.doi.org/10.1016/ j.healthplace.2016.04.011.

Przeworski, A., 2000. Democracy and Development: Political Institutions and Well- 
being in the World, 1950-1990. Cambridge University Press.

Reinikka, R., Svensson, J., 2005. Fighting corruption to improve schooling: evidence from a newspaper campaign in Uganda. J. Eur. Econ. Assoc. 3, 259-267.

Ross, M.L., 2006. Is democracy good for the poor? Am. J. Polit. Sci. 50, 860-874.

Ross, M.L., Mahdavi, P., 2015. Oil and gas data, 1932-2014 [WWW document]. Harvard dataverse. http://dx.doi.org/10.7910/DVN/ZTPWOY. (Accessed 22 July 2016).

Sen, A., 2009. The Idea of Justice. Harvard University Press, Cambridge Mass.

Sen, A., 1999. Development as Freedom. Anchor Books, New York.

Shandra, J.M., Nobles, J., London, B., Williamson, J.B., 2004. Dependency, democracy, and infant mortality: a quantitative, cross-national analysis of less developed countries. Soc. Sci. Med. 59, 321-333. http://dx.doi.org/10.1016/ j. socscimed 2003,10.022.

Soares, R., 2005. Mortality reductions, educational attainment, and fertility choice. Am. Econ. Rev. 95, 580-601.

Stromberg, D., 2004. Radio's impact on public spending. Q. J. Econ. 119, 189-221.

Truex, R., 2015. The Myth of the Democratic Advantage. St Comp Int Dev, pp. 1-17. http://dx.doi.org/10.1007/s12116-015-9192-4.
UN Inter-Agency Group for Child Mortality Estimation (UN IGME), 2016. Child mortality estimates [WWW document]. http://www.childmortality.org/.

Vanhanen, T., 2014. Measures of democracy 1810-2012, FSD1289, version 6.0 (2014 01-31) [WWW document]. Tampere: Finnish social science data archive. http:/ www.fsd.uta.fi/en/data/catalogue/FSD1289/meF1289e.html.

Whitten-Woodring J Van Belle, D.A. 2014. Historical Guide to World Media Freedom: a Country-by-Country Analysis. CQ Press, Washington, DC.

Wigley, S., 2017. The resource curse and child mortality, 1961-2011. Soc. Sci. Med. 176, 142-148, http://dx.doi.org/10.1016/j.socscimed 2017.01.038.

Wigley, S., Akkoyunlu, A., 2011. The impact of regime type on health: does redistribution explain everything? World Polit. 63, 647-677. http://dx.doi.org $10.1017 /$ S0043887111000177.

World Bank, 2016. World development indicators 2016 [WWW document]. http:/ data.worldbank.org/data-catalog/world-development-indicators.

Yazbeck, A.S., 2009. Attacking Inequality in the Health Sector. World Bank, Washington D.C.

Zweifel, T.D., Navia, P., 2000. Democracy, dictatorship, and infant mortality. J. Democr. 11, 99-114. http://dx.doi.org/10.1353/jod.2000.0047. 